\title{
Photochemistry of Luffa cylindrica (L.) Roem under fungal biocontrol interaction
}

\author{
H. AMRINA*, S. SHAHZAD ${ }^{* *}$, and Z.S. SIDDIQUI ${ }^{*+}$
}

Stress Physiology Phenomic Laboratory, Department of Botany, University of Karachi, Karachi-75270, Pakistan* Department of Agriculture and Agribusiness Management, University of Karachi, Karachi-75270, Pakistan ${ }^{* *}$

\begin{abstract}
The aim of this study was to evaluate the photochemistry of Luffa cylindrica (L.) Roem in fungal biocontrol interacting treatments. Healthy plants were infected with Pythium aphanidermatum before the biocontrol application. Biocontrol agents were selected in preliminary Petri-plate experiment evaluation against causative agent $P$. aphanidermatum. Photosynthetic performance traits were studied. We found that $P$. aphanidermatum infection caused significant reduction in photosynthetic performance, pigments, and in maximum quantum yield of primary photochemistry, photochemical quenching, and electron transport rate with increase in nonphotochemical quenching as compared with non-infected control. However, application of biocontrol agents substantially improved maximum quantum yield of PSII, performance index, and total content of photosynthetic pigments in infected plants. The fluorescence intensity was used for quantifying the antagonist effect of biocontrol agents on infected plant leaves.
\end{abstract}

Additional key words: chlorophyll fluorescence transient; photochemistry; photoinhibition.

\section{Introduction}

Luffa cylindrica (L.) Roem, a member of the Cucurbitaceae family, is found in tropical and subtropical areas in Pakistan (Perveen and Qaiser 2008). Bottle gourd and sponge gourd are the popular plants of this family. Damping-off and root rot on greenhouse cucurbits are caused by a number of Pythium spp. (Abad et al. 1994, Abdelzaher et al. 2004). Pythium is the recurring problems for growers in Sindh, Pakistan. In Sindh, damping-off and root rot are during the summer generally caused by Pythium aphanidermatum (Edson) Fitzp (Hendrix and Campbell 1973, Lodhi et al. 2013). Over the last few decades, chemical herbicides and pesticides are used for crop management strategies in developing countries (Wyse 1992, Albernathy and Bridges 1994, Coombs 2012), but their residual consequence has diverted the intention of scientists toward alternate means for controlling infection.

Chemical pesticides, more stringent and costly regeneration regulations, and the necessity for alternatives in environmentally sensitive areas provide avenues for the use of plant pathogens as biocontrol agents (Larkin and Fravel 2002, Muthukumar et al. 2008, 2010). Treatment with biocontrol agents has been shown to be highly effective in promoting growth when dormancy is related to fungal stress (Dawar et al. 2008). To overcome the pathogenic effect, biological control may provide an additional method for the management of pests or pathogens. According to literature, Trichoderma harzianum, Paecilomyces variotii, and Bacillus subtilis are established against pests or pathogens (Klein 1990, Glick 1995, Postma et al. 2003, Khan et al. 2008, Agrios 2005, Perner et al. 2006, Jeyaseelan et al. 2012). However, most of the research is restricted to show control of the disease, but their physiological mechanism of controlling disease and photochemistry of infected plants are not provided. Photosynthesis contributes substantially to the plant growth and development. A number of reports showed that under fungal stress values of maximum quantum yield of

Received 27 July 2016, accepted 6 March 2017, published as online-first 26 April 2017.

${ }^{+}$Corresponding author; e-mail: zaminss@uok.edu.pk

Abbreviations: Chl - chlorophyll; $\mathrm{C}$ - control; $\mathrm{F}_{\mathrm{v}} / \mathrm{F}_{\mathrm{m}}-$ maximum quantum yield of PSII; NPQ - nonphotochemical quenching; PDA potato dextrose agar; PI - performance index; Py - Pythium aphanidermatum; $\mathrm{Py}+\mathrm{Ba}-$ Pythium aphanidermatum + Bacillus subtilis; qP - photochemical quenching; $\mathrm{Py}+\mathrm{Pa}-$ Pythium aphanidermatum + Paecilomyces variotii; $\mathrm{Py}+\mathrm{T}-$ Pythium aphanidermatum + Trichoderma harzianum; rETR - electron transport rate through PSII; $\Phi_{\mathrm{PSII}}$ - maximum quantum yield of primary photochemistry. Acknowledgment: Authors are thankful to Dean of Faculty of Science and Department of Botany, University of Karachi for financial and material support throughout the research work. 
PSII $\left(\mathrm{F}_{\mathrm{v}} / \mathrm{F}_{\mathrm{m}}\right)$, photochemcial quenching $\left(\mathrm{q}_{\mathrm{p}}\right)$, electron transport rate through PSII (rETR) and maximum quantum yield of primary photochemistry $\left(\Phi_{\text {PSII }}\right)$ were very low due to the low content of photosynthetic pigments.

On the basis of these findings it is tempting to speculate that the selected biocontrol agents, $T$. harzianum, $P$. variotii and $B$. subtilis, might be involved in reducing infection due to fungal biocontrol interaction thereby ensure resistance against the pathogen. However, limited information is

\section{Materials and methods}

Seeds of Luffa cylindrica (L.) Roem were obtained from the stock collection of Pathology laboratory, Department of Agriculture and Agri-business Management, University of Karachi. The seeds were sterilized in 5\% sodium hypochlorite solution for $5 \mathrm{~min}$ before experiments. Twenty seeds per Petri plate with internal diameter of $8 \mathrm{~cm}$ were used for pelleting. Petri dishes were arranged in a completely randomized design with three different treatments. Each treatment was replicated thrice.

Dual culture interaction: Melted potato dextrose agar (PDA) $(20 \mathrm{ml})$ was poured in each Petri plates and allowed to solidify. A disc of $9 \mathrm{~mm}$ with the actively growing colonies of pathogenic culture ( $P$. aphanidermatum, Py ) were placed near the periphery on one side of the PDA; 9 $\mathrm{mm}$ disc of test organisms, such as Trichoderma harzianum (T), Paecilomyces variotii $(\mathrm{Pa})$, and Bacillus subtilis $(\mathrm{Ba})$ were placed on the other side of same plate at an angle of 180 degree. The plates were incubated at $28^{\circ} \mathrm{C}$ available concerning the persistence of T.harzianum, $P$. variotii, and $B$. subtilis co-applied against damping-off disease. Objectives of this research were to determine how this biocontrol agent suppresses Pythium aphanidermatum infection in L. cylindrica. In this connection, an explanatory assessment required to determine the overall photosynthetic performance through chlorophyll fluorescence parameter under fungal biocontrol interaction.

for $5 \mathrm{~d}$ and colony growth inhibition (\%) was calculated (see the text table below; Fig. 1).

A, B, C, D were the pure culture growing alone without interaction, whereas $\mathrm{E}, \mathrm{F}, \mathrm{G}, \mathrm{H}$ were the dual culture interaction in which tested organism grew along with pathogen.

\section{Selection of biocontrol agents}

Fungal inoculation and experimental design: L. cylindrica seeds were pelleted with biocontrol agents $\mathrm{T}, \mathrm{Pa}$, and Ba grown on PDA plates by the method of Fouzia and Shahzad (2008). The number of colonies per plate was multiplied with the dilution factor and then divided by 5 to determine the spore-load per seed. The plastic pot areas of $153.2 \mathrm{~cm}^{2}$ were filled with $300 \mathrm{~g}$ of sandy loam soil. The whole experiment was carried out in a greenhouse. The seedling were allowed to grow at a temperature of $30-35^{\circ} \mathrm{C}$, relative humidity of $60-65 \%$, and light intensity at the top of plants was $42-45.5 \mu \mathrm{mol}$ (photon) $\mathrm{m}^{-2} \mathrm{~s}^{-1}$.

\begin{tabular}{lllll}
\hline Test fungi & $\begin{array}{l}\text { Colony diameter [mm] } \\
\text { Pathogen (fungus) }\end{array}$ & $\begin{array}{l}\text { Biocontrol agent } \\
\text { (test microorganism) }\end{array}$ & Type of interaction & Growth inhibition [\%] \\
\hline P. aphanidermatum + T. harzianum & 1.8 & 5.6 & $\mathrm{~A}$ & 77.50 \\
P. aphanidermatum + P. variotii & 2.95 & 4.67 & $\mathrm{~B}$ & 36.83 \\
P. aphanidermatum + B. subtilis & 2.5 & 6.0 & $\mathrm{C}$ & 58.33 \\
\hline
\end{tabular}

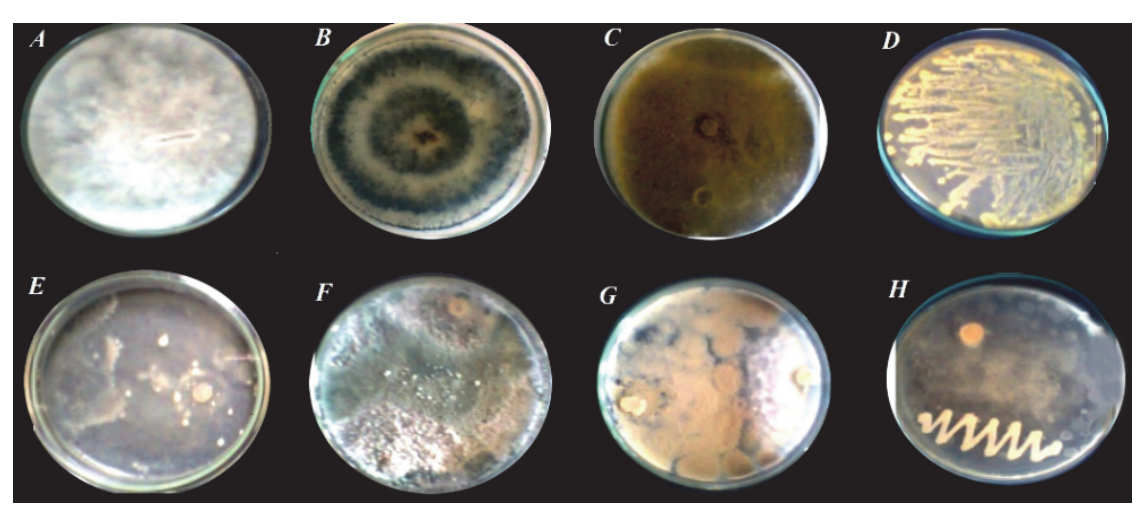

Fig. 1. Pure microbe isolates and their dual culture interaction on potato dextrose agar and nutrient agar medium. Pure culture of $(A)$ Pythium aphanidermatum, $(B)$ Trichoderma harzianum, $(C)$ Paecilomyces variotii, $(D)$ Bacillus subtilis. Dual culture interaction of $(E)$ Bacillus subtilis against Pythium aphanidermatum, $(F)$ Trichoderma harzianum against Pythium aphanidermatum, $(G)$ Paecilomyces variotii against Pythium aphanidermatum, $(H)$ Bacillus subtilis against Pythium aphanidermatum. 
Treated seed with and without pathogen: The 30 nonpelleted seeds of each control and $P$. aphanidermatum $\left[1 \times 10^{-3}\right.$ colony forming unit $\left.(\mathrm{cfu}) \mathrm{mL}^{-1}\right]$ were sown in ten pots and 90 pelleted seeds with $20 \mathrm{~mL}^{-1}$ of T.harzianum $\left(1.16 \times 10^{-1} \mathrm{cfu} \mathrm{mL} \mathrm{mL}^{-1}\right), P$. variotii $\left(2.5 \times 10^{-2} \mathrm{cfu} \mathrm{mL}^{-1}\right)$, and B.subtilis $\left(6.3 \times 10^{-1} \mathrm{cfu} \mathrm{mL}^{-1}\right)$ were sown in 30 pots.
The plants were subjected to same experimental conditions mentioned above. There were five replicates for each treatment. Plants were uprooted after $30 \mathrm{~d}$ in order to assess physiological attributes. The information regarding the applied treatments were given in the following text table:

\begin{tabular}{llll}
\hline $\begin{array}{l}\text { Treament } \\
\text { Negative Control }\end{array}$ & $\begin{array}{l}\text { Causative agents } \\
\text { P. aphanidermatum }\end{array}$ & $\begin{array}{l}\text { Concentration }\left[\mathrm{cfu} \mathrm{mL}^{-1}\right] \\
1 \times 10^{-3}\end{array}$ & {$[\mathrm{Py}]$} \\
\hline Positive Control 1 & T. harzianum & $1.16 \times 10^{-1}$ & {$[\mathrm{~T}]$} \\
Positive Control 2 & P. variotii & $2.5 \times 10^{-2}$ & {$[\mathrm{~Pa}]$} \\
Positive Control 3 & B. subtilis & $6.3 \times 10^{-1}$ & {$[\mathrm{Ba}]$} \\
Treatment 1 & T. harzianum + P. aphanidermatum & {$[\mathrm{Py}+\mathrm{T}]$} & \\
Treatment 2 & P. variotti + P. aphanidermatum & {$[\mathrm{Py}+\mathrm{Pa}]$} & \\
Treatment 3 & B. subtilis + P. aphanidermatum & {$[\mathrm{Py}+\mathrm{Ba}$} & \\
\hline
\end{tabular}

Photosynthetic pigments: Leaf discs of $0.5 \mathrm{~g}$ were extracted in $10 \mathrm{~mL}$ of methanol $(95 \%)$, homogenized, and centrifuged at $10,000 \mathrm{rpm}$ for $10 \mathrm{~min}$, The absorbance of the solution was measured at 666,653 , and $470 \mathrm{~nm}$ by a spectrophotometer (Shimadzu, Japan). Total photosynthetic pigments were calculated using the equation of Lichtenthaler and Wellburn (1985) and Ritchie (2008).

$$
\begin{aligned}
& \text { Chl } a=15.65 \mathrm{~A}_{666}-7.340 \mathrm{~A}_{653} \\
& \text { Chl } b=27.05 \mathrm{~A}_{653}-11.21 \mathrm{~A}_{666} \\
& \text { Carotenoids }(\mathrm{Cx}+\mathrm{c})= \\
& =\left(1,000 \mathrm{~A}_{470}-2.860 \mathrm{Chl} a-129.2 \mathrm{Chl} b\right) / 245
\end{aligned}
$$

Chl fluorescence: Photosynthetic efficiency was measured in L. cylindrica by an analyzer Os-30p (OPTISCIENCES, USA). The data obtained were used to calculate various parameters that describe the photo-

\section{Results}

Selection and activity of biocontrol agents against pathogen Py were tested at Petri plates. The T, Pa, and Ba culture were used against Py (Fig. 1). Results showed that $\mathrm{T}$ exhibited the maximum $(67.9 \%)$ growth inhibition as compared to other biocontrol agents. Ba showed 58.3\%, and $\mathrm{Pa}$ exhibited $36.8 \%$ growth inhibition (Fig. 1, text table).

In pot experiments, two-week old seedlings were inoculated by the spore suspensions of Py $\left(1 \times 10^{-3} \mathrm{cfu} \mathrm{mL}^{-1}\right)$. During the disease development, visible discoloration effect was observed in the form of yellowish green leaves. Py inoculation significantly reduced a growth and biomass allocation of treated plants as compared with untreated control (C) (Fig. 2). However, the application of biocontrol agents enhanced plant growth and biomass in the infected plants. All the applied biocontrol agents were able to increase seedling growth including root and shoot length as compared with their negative control (infected plants only). Maximum increase of the whole plant biomass was recorded when infected plants were subjected to T. harzianum $(\mathrm{Py}+\mathrm{T})$. Photosynthetic attributes were chemistry of PSII by the JIP test and $\mathrm{F}_{\mathrm{v}} / \mathrm{F}_{\mathrm{m}}, \Phi_{\mathrm{PSII}}, \mathrm{q}_{\mathrm{P}}, \mathrm{rETR}$, PI, and NPQ (Strasser et al. 2004). The data were collected from attached leaves at ambient temperature. Samples of 48 leaves per 16 replicates were taken for the Chl fluorescence analysis (ChlF). The leaf clips were placed on the leaves $20 \mathrm{~min}$ to prior the measurements to provide dark adaptation. The light-pulse intensity was 3,500 $\mu \mathrm{mol}$ (photon) $\mathrm{m}^{-2} \mathrm{~s}^{-1} . \mathrm{F}_{\mathrm{v}} / \mathrm{F}_{\mathrm{m}}$, performance index (PI), $\mathrm{q}_{\mathrm{P}}, \Phi_{\mathrm{PSII}}$, NPQ, and rETR were calculated according to the equations reviewed by Stirbet and Govindjee (2011).

Statistical analysis: The data were subjected to Sigma Plot version 13.0 to performed analysis of variance $(A N O V A)$ and $F$-test. Similar alphabets on graph represent insignificant difference at 0.05 . The vertical line on bar graph showed mean \pm standard error (SE).

examined in the infected plant after their biocontrol treatments. The infected plants subjected to biocontrol treatments displayed significant increase in the $F_{v} / F_{m}$ ratio. Biocontrol treatment $\mathrm{Py}+\mathrm{T}$ caused 64\% enhancement, while treatment $\mathrm{Py}+\mathrm{Pa}$ and treatment $\mathrm{Py}+\mathrm{Ba}$ showed $61-$ $62 \%$ increase compared to Py-infected plants. In infected plants, PI was substantially reduced at the average rate against untreated control (Fig. 3B). However, application of biocontrol agents improved the PI in Py-infected plants. Thus, $\mathrm{Py}+\mathrm{Ba}$ treatment exhibited 98\% enhancement, while $\mathrm{Py}+\mathrm{T}$ and $\mathrm{Py}+\mathrm{Pa}$ showed $96 \%$, respectively.

Our results revealed that $\Phi_{\text {PSII }}$ decreased under fungal stress of Py. Application of biocontrol treatment T. harzianum and B. subtilis exhibited higher $\Phi_{\mathrm{PSII}}(63 \%)$ in infected plant as compared with their negative control (Fig. 3E).

Py infection exhibited $41 \%$ decrease in $\mathrm{q}_{\mathrm{P}}$, which indicated closure of reaction centers. However, the application of biocontrol agents suppressed the effect of pathogen up to $27-46 \%$ (Fig. $2 C$ ). 

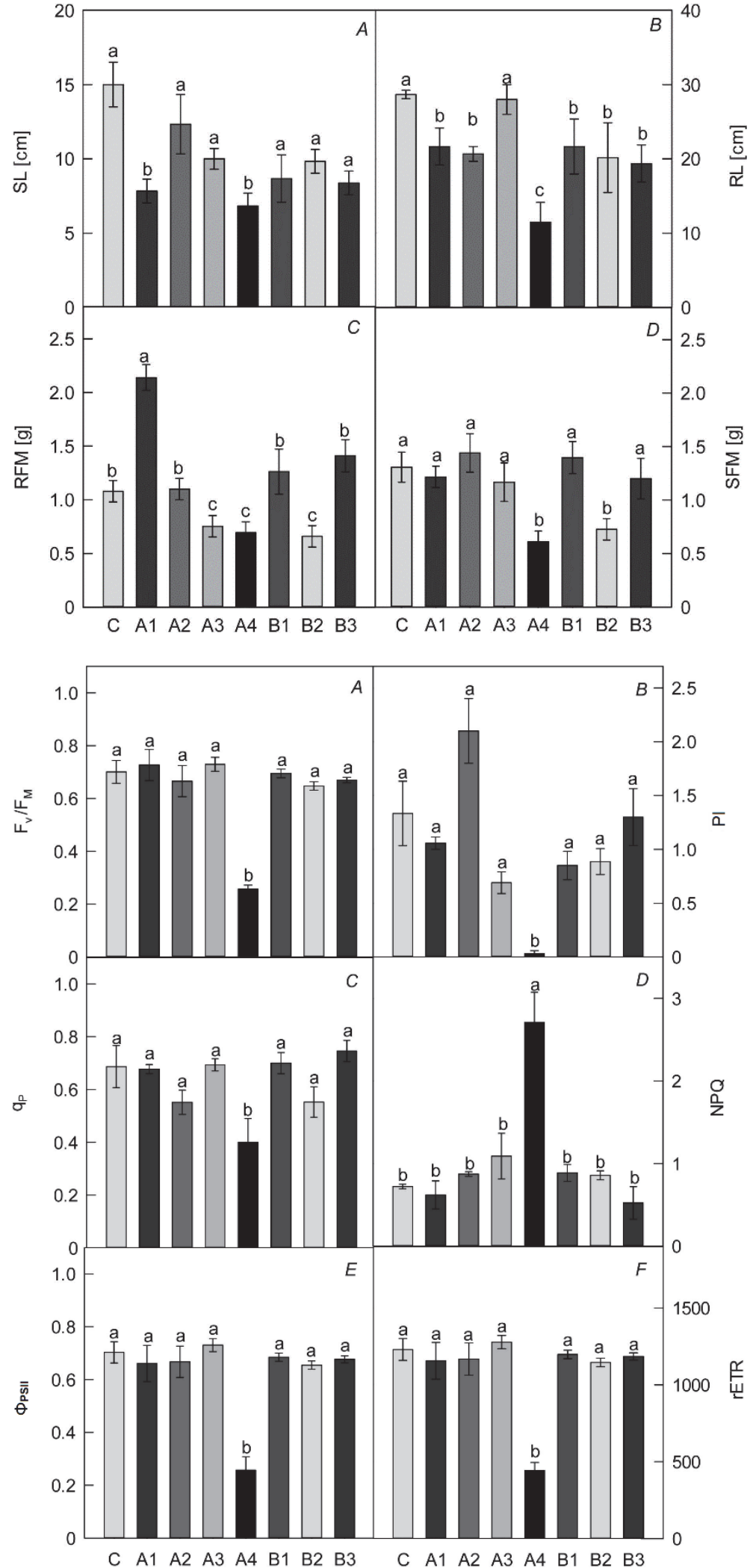

Fig. 2. Effect of biocontrol treatments on the shoot length (SL), root length (RL), root fresh mass (RFM), and shoot fresh mass (SFM) of Luffa cylindrica. C Control, A1 - Trichoderma harzianum, A2 - Paecilomyces variotii, A3 - Bacillus subtilis, A4 Pythium aphanidermatum. $\mathrm{B} 1-\mathrm{Py}+\mathrm{T}, \mathrm{B} 2-\mathrm{Py}+\mathrm{Pa}$, B3 - Py+Ba. Vertical lines on bar graphs represent mean $\pm \mathrm{SE}$. The same letters show insignificant difference at $p<0.05$ level according to one-way $A N O V A$ and $F$ - test.

Fig. 3. Effect of fungal biocontrol treatment on maximum quantum yield of PSII $\left(\mathrm{F}_{\mathrm{v}} / \mathrm{F}_{\mathrm{m}}\right)$, performance index (PI), photochemical quenching $(\mathrm{qP})$, nonphotochemical quenching (NPQ), maximum quantum yield of primary photochemistry ( $\left.\Phi_{\mathrm{PSII}}\right)$, electron transport rate through PSII (rETR) of Luffa cylindrica leaf. C - control, A1 - Trichoderma harzianum, A2 - Paecilomyces variotii, A3 - Bacillus subtilis, A4 - Pythium aphanidermatum. B1 $\mathrm{Py}+\mathrm{T}, \mathrm{B} 2-\mathrm{Py}+\mathrm{Pa}, \mathrm{B} 3-\mathrm{Py}+\mathrm{Ba}$. Vertical lines on bar graphs represent mean $\pm \mathrm{SE}$ The same letters show insignificant difference at $p<0.05$ level, According to one-way $A N O V A$ and $F$ - test.

In Py-infected plants, NPQ drastically increased by $90 \%$ as compared with $\mathrm{C}$ and biocontrol treatments (Fig. 3D). The drop in NPQ up to $33-68 \%$ was more accentuated by biocontrol treatments as compared to the infected plants. In the infected plants (infected plants represented as A4 on bar graph), the greater increase in 


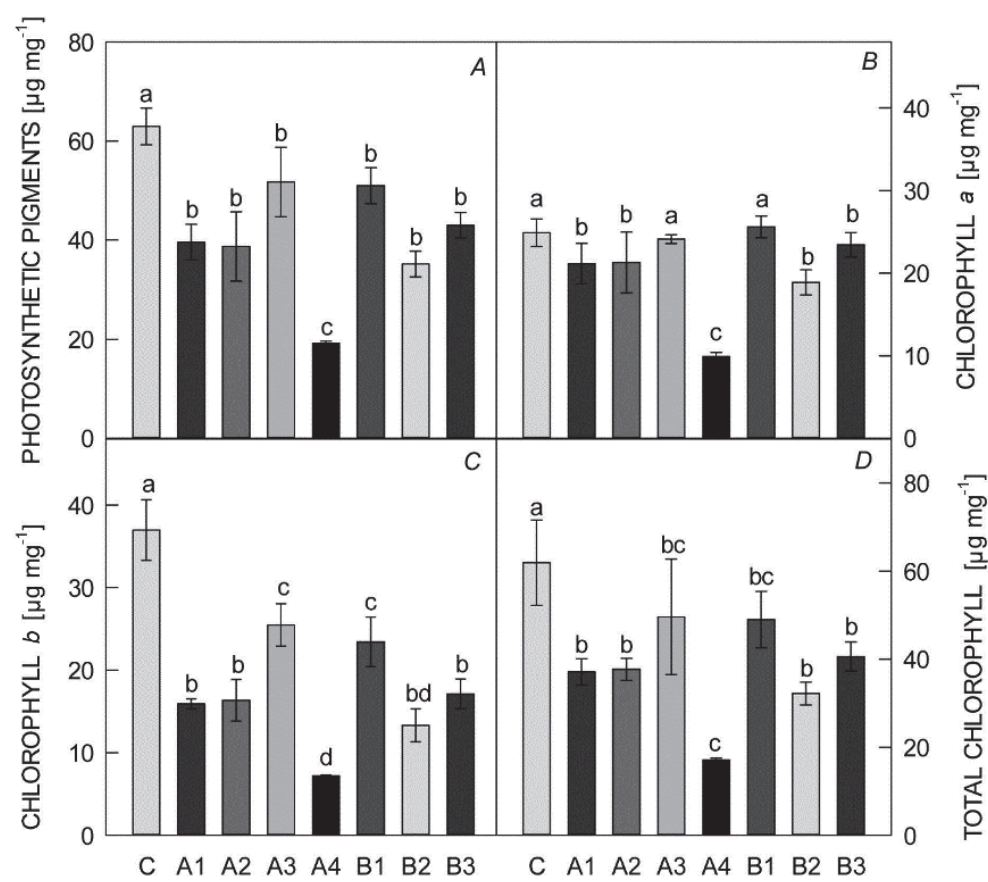

Fig. 4. Effect of fungal biocontrol interaction on photosynthetic pigments $\mu \mathrm{g} \mathrm{mg}^{-1}(\mathrm{Chl} a, \mathrm{Chl} b$, total $\mathrm{Chl}$, and Car) of L. cylindrica. C - control, A1 Trichoderma harzianum, A2 - Paecilomyces variotii, A3 - Bacillus subtilis, A4 - Pythium aphanidermatum and $\mathrm{B} 1-\mathrm{Py}+\mathrm{T}, \mathrm{B} 2-\mathrm{Py}+\mathrm{Pa}, \mathrm{B} 3-\mathrm{Py}+\mathrm{Ba}$. Vertical lines on bar graphs represent mean $\pm \mathrm{SE}$. The same letters show insignificant difference at $p<0.05$ level according to one-way $A N O V A$ and $F$ - test.

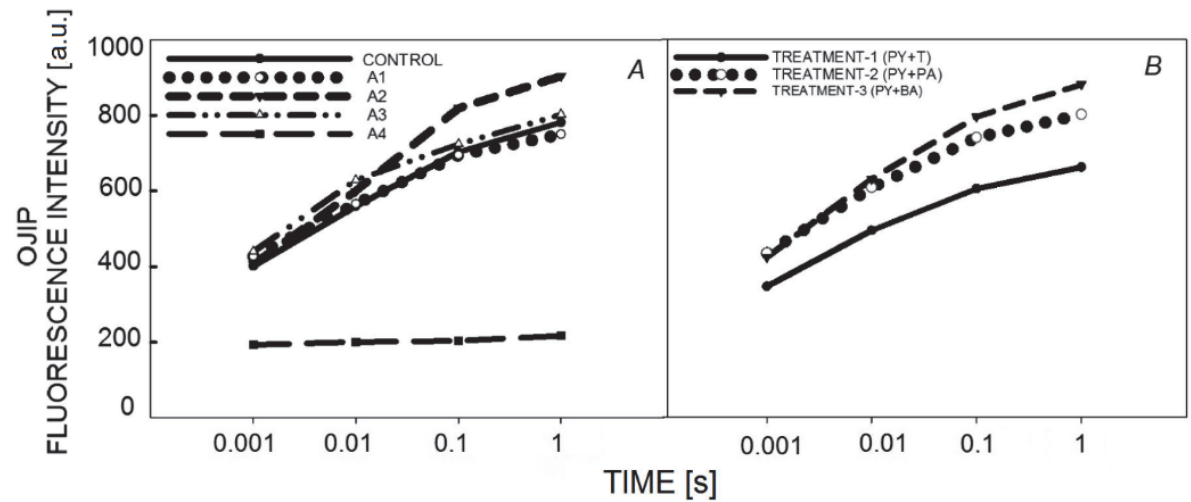

Fig. 5. Fluorescence induction curve (OJIP) estimating Luffa cylindrica leaves under stress and treatment. $\mathrm{C}$ - control, A1 - Trichoderma harzianum, A2 - Paecilomyces variotii, A3 - Bacillus subtilis, A4 - Pythium aphanidermatum and $\mathrm{B} 1-\mathrm{Py}+\mathrm{T}, \mathrm{B} 2$ $-\mathrm{Py}+\mathrm{Pa}, \mathrm{B} 3-\mathrm{Py}+\mathrm{Ba}$.
NPQ was accompanied by a substantial decrease in $\Phi_{\text {PSII }}$ up to $64 \%$ during the course of experiment. As rETR is derived from $\Phi_{\text {PSII }}$ value indicated (Fig. $2 E, F$ ) that the application of biocontrol treatments enhanced of rETR and $\Phi_{\text {PSII }}$ activity up to $61-63 \%$ as compared to infected plants.

In the infected plants, photosynthetic pigments decreased by $65 \%$ as compared with untreated control (Fig. 4). However, application of biocontrol agents, such as treatment by $\mathrm{Py}+\mathrm{T}$ and $\mathrm{Ba}+\mathrm{T}$, showed significant increase in Chl $a$ and $b$ and total Chl up to 58-65\%. Maximum increase in photosynthetic pigments was found in the infected plant exposed to T. harzianum. In infected

\section{Discussion}

Present study revealed that $T$. harzianum as a biocontrol treatment was highly effective in inhibiting the mycelial growth of $P$. aphanidermatum (the damping-off disease) in $L$. cylindrica. We observed that $P$. aphanidermatum- plants the photosynthetic pigment contents including Chl $a, b$ and total Chl was relatively lowered up to $45-48 \%$ as compared to biocontrol treatments (Fig. 4).

Our results further confirmed by the OJIP test showed that in infected plants the fluorescence intensity at 3,500 $\mu \mathrm{mol}$ (photon) $\mathrm{m}^{-2} \mathrm{~s}^{-1}$ PAR substantially declined up to the injurious level at $200 \mu \mathrm{mol}$ (photon) $\mathrm{m}^{-2} \mathrm{~s}^{-1}$ PAR (Fig. 5A). Biocontrol treatments caused that fluorescence intensities were enhanced from 400 to $900 \mu \mathrm{mol}$ (photon) $\mathrm{m}^{-2} \mathrm{~s}^{-1}$ which showed effective enhancement of the photosynthetic rate leading to better yield of the plant (Fig. 5B).

infected plants demonstrated the significant reduction in photosynthetic pigments $(65 \%), \mathrm{F}_{\mathrm{v}} / \mathrm{F}_{\mathrm{m}}, \Phi_{\text {PSII }}$, rETR (64\%), $\mathrm{q}_{\mathrm{P}}(41 \%)$, PI $(98 \%)$, and NPQ, which presented $90 \%$ inhibition, but treatment by $T$. harzianum showed 
stimulating effect compared to other treatments. It was observed that $T$. harzianum enhanced photosynthetic performance up to $60 \%, \mathrm{~F}_{\mathrm{v}} / \mathrm{F}_{\mathrm{m}}(64 \%), \Phi_{\text {PSII }}$, and $\mathrm{rETR}$ $(64 \%)$, PI $(96 \%)$, qP $(52 \%)$, and NPQ $(32 \%)$ in infected plants as compared to negative control (infected plants only)

It was reported that increase in NPQ is based on downregulation of PSII function under fungal infection (Singh et al 2013). On the other hand, similar result were found in our experiment; NPQ attained the highest level up to $90 \%$ under fungal stress. The $\mathrm{F}_{\mathrm{v}} / \mathrm{F}_{\mathrm{m}}$ ratio is an important parameter, which determines the maximum quantum efficiency of PSII. It provides a measure of the rate of linear electron transport, hence, an indication of overall photosynthetic capacity (Jamil et al. 2007, Tang et al. 2007, Balouchi 2010). Similarly, a decline in $F_{v} / F_{m}$ value below 0.7 occurs due to photoinhibition caused by the pathogen $P$. aphanidermatum subsequently decreased $\mathrm{q}_{\mathrm{P}}$ value to 0.4 . It was observed that reaction centers activity was reduced due to the reduction of photochemistry and their $\mathrm{F}_{\mathrm{v}} / \mathrm{F}_{\mathrm{m}}, \Phi_{\mathrm{PSII}}, \mathrm{rETR}$ and $\mathrm{q}_{\mathrm{P}}$ values. It showed the possibility of energy transfer between the two photosystem were disconnected due to the infection. It was evident from our research that microbial biocontrol agents not only inhibited plant infection but also promoted photosynthetic efficiency of the plants.

The application of biocontrol treatments showed an effective response in the infected plants with respect to growth and photosynthetic efficiency. The spore of $P$. aphanidermatum induced substantial reduction in seedling growth and biomass allocation. However, application of $T$. harzianum to infected plants increased seedling growth and biomass up to $45-71 \%$.

Some positive correlation was found under the $\mathrm{Py}+\mathrm{Ba}$ treatment, which was linked to the photosynthetic performance. Increased NPQ up to $68 \%$ due to the induction of pathogen was significant at low light level (Schroth and Becker 1990, van Peer et al. 1991, Maxwell and Johnson 2000, Yuan 2016). The decrease of PI, $F_{v} / F_{m}$, $\Phi_{\text {PSII }}$, and rETR supported marked physiological effects on the infected plants showing sensitivity to pathogen. The

\section{References}

Abad Z.G., Shew H.D., Lucas L.T.: Characterization and pathogenicity of Pythium species Isolated from turf grass with symptoms of root and crown rot in North Carolina. Phytopathology 84: 913-921, 1994.

Abdelzaher H.M.A., Imam M.M., Shoulkamy M.A., Gherbawy Y.M.A.: Biological control of Pythium damping-off of bush okra using rhizosphere strains of Pseudomonas fluorescens. Mycobiology 32: 139-147, 2004.

Albernathy J.R., Bridges D.C.: Research priority dynamics in weed science. - Weed Technol. 8: 396-399, 1994.

Baker N.R., Rosenquist E.: Applications of chlorophyll fluorescence can improve crop production strategies: an examination of future possibilities. - J. Exp. Bot. 55: 1607$1621,2004$.

Balouchi H.R.: Screening wheat parents of mapping population selected biocontrol agents showed their efficacy individually or interacting with the pathogen which effectively enhanced the photosynthetic rate; similar results were also reported by Vargas et al. (2009).

In infected plants, total photosynthetic pigments decreased after the induction of fungal pathogen, while applying biocontrol agents improved the Chl concentration. The $\mathrm{Py}+\mathrm{T}$ treatment showed maximum enhancement in the total $\mathrm{Chl}$ content of infected plants up to $65 \%$ as comapred to negative control (infected plant only) indicating the suppressing effect against infection. It was reported that infection in plants causes reduction in photosynthetic pigment which can inhibit plant growth but also induce photoinhibition (Baker and Rosenqvist 2004, Zlatev 2009, Vaz and Sharma 2011). Similarly high activities of electron transport chain were observed after the $\mathrm{Py}+\mathrm{T}$ and $\mathrm{Py}+\mathrm{Ba}$ treatments ameliorating 63\% photoinhibition of PSII. It is assumed that linear correlation between $\Phi_{\text {PSII }}$ and ETR values due to biocontrol treatments in infected plants indicated sufficient electron movement in the photosynthetic pathways which not only demonstrated enhancement in photosynthetic ability but also reflected better plant growth.

The OJIP transients were also analyzed and correlated with the internal leaf quality and they positively coincided with photosynthetic performance. The JIP test showed that fungal infection in plants significantly decreased the OJIP values representing the inhibition in Chl excitation activity as compared with untreated control (Fig. 5). However, the application of biocontrol agents revealed enhancement in OJIP parameters as compared to the infected plant which indicated improvement in electron flow under infection; the $\mathrm{Py}+\mathrm{Ba}$ treatment showed the highest OJIP parameters as compared to other treatments.

Based on the present study, we can conclude that the antagonistic effects of biocontrol treatments, such as T. harzianum, P. variotti, and B.subtilis enhanced the photosynthetic activity of $L$. cylindrica which not only suppressed plant infection but also improved plant growth.

for heat and drought tolerance, detection of wheat genetic variation. - Int. J. Biol. Life Sci. 6: 56-66, 2010.

Dawar S, Hayat S, Anis M. et al.: Effect of seed coating material in the efficacy of microbial antagonists for the control of root rot fungi on okra and sunflower. - Pak. J. Bot. 40: 1269-1278, 2008.

Fouzia Y., Shahzad S.: Effect of seed pelleting with Trichoderma spp., and Gliocladium virens on growth and colonization of roots of sunflower and mung bean by Sclerotium rolfsii. - Pak. J. Bot. 40: 947-953, 2008.

Glick B.R.:The enhancement of plant growth by free-living bacteria. - Can. J. Microbiol. 41: 109-117, 1995.

Hendrix F.F., Campbell W.A.: Pythium as plant pathogens. Annu. Rev. Phytopathol. 11: 77-98, 1973.

Jamil M., Rehman S., Lee K.J. et al.: Salinity reduced growth 
PS2 photochemistry and chlorophyll content in radish. - Sci. Agr. 64: 111-118, 2007.

Jeyaseelan E.C., Vinuja T., Pathmanathan K.: Control of plant pathogenic fungi using organic solvent extracts of leaf, flower and fruit of Lawsonia inermis (L). - Int. J. Pharm. Biol. Sci. Arch. 3: 783-788, 2012.

Khan Z.R, James D.G., Midega C.A.O.: Chemical ecology and conservation biological control. - Biol. Control 45: 210-224, 2008.

Klein M.G.: Efficacy against soil inhibiting pests. - In: Gaugler R., Kaya H.K. (ed.): Entomopathogenic Nematodes in Biological Control Pp. 195-231, CRC Press, Boca Raton 1990.

Larkin R.P., Fravel D.R.: Effects of varying environmental conditions on biological control of Fusarium wilt of tomato by nonpathogenic Fusarium spp. - Phytopathology 92: 11591166, 2002.

Lichtenthaler H.K., Welburn A.R.: Determination of total carotenoids and chlorophylls $a$ and $b$ of leaf extracts in different solvents. - Biochem. Soc. Trans. 11: 591-592, 1985.

Liu Y.C., Liu C.H., Lin C.Y. et al.: Effect of low irradiance on the photosynthetic performance and spiking of Phalaenopsis. Photosynthetica 54: 259-266, 2016.

Lodhi A.M., Khanzada M.A., Shahzad S. et al.: Prevalence of Pythium aphanidermatum in agro-ecosystem of Sindh province of Pakistan. - Pak. J. Bot. 45: 635-642, 2013.

Maxwell K., Johnson GN.: Chlorophyll fluorescence - a practical guide. - J. Exp. Bot. 51:659-668, 2000.

Muthukumar A.: Management of chilli damping off cause by Pythium aphanidermatum (Edson) Fitz with bacterial endophytes (Pseudomonas fluorescens) in glass house condition. Adv. Plant Sci. 21: 295-298, 2008.

Muthukumar A., Eswaran A., Nakkeeran S. et al.: Efficacy of plant extracts and biocontrol agents against Pythium aphanidermatum inciting chilli damping-off. - Crop Prot. 29: 1083-1088, 2010.

Perner H., Schwarz D., George E.: Effect of mycorrhizal inoculation and compost supplyon growth and nutrient uptake of young leek plants grown on peat-based substrates. HortScience 41: 628-632, 2006.

Perveen A., M. Qaiser: Pollen flora of Pakistan-LVI. Cucurbitaceae. - Pak. J. Bot. 40: 9-16, 2008.

Postma J., Montanari M., van den Boogert P.H.J.F.: Microbial enrichment to enhance disease suppressive activity of compost. - Eur. J. Soil. Biol. 39: 157-163, 2003.
Ritchie R.J.: Universal chlorophyll equations for estimating chlorophylls $a, b, c$, and $d$ and total chlorophylls in natural assemblages of photosynthetic organisms using acetone, methanol or ethanol solvents. - Photosynthetica 46: 115-126, 2008.

Schroth M.N., Becker J.O.: Concepts of ecological and physiological activities of rhizobacteria related to biological control and plant growth promotion. - In: Horn D. (ed.): Biological Control of Soil-Borne Plant Pathogens. Pp. 380414. CAB International, Wallingford 1990.

Singh V.P., Srivastava P.K., Prasad S.M.: Nitric oxide alleviates arsenic induced toxic effects in ridged Luffa seedlings. - Plant Physiol. Bioch. 71: 155-163, 2013.

Stirbet A., Govindjee.: On the relation between the Kautsky effect (chlorophyll $a$ fluorescence induction) and Photosystem II: basics and applications of the OJIP fluorescence transient J. Photoch. Photobio. 104: 236-257, 2011.

Strasser A., Tsimilli-Michael M., Srivastava A.: Analysis of the fluorescence transient. - In: Papageorgiou G.C., Govindjee (ed.): Chlorophyll $a$ Fluorescence: A Signature of Photosynthesis. Pp. 321-362. Springer, Dordrecht 2004.

Tang Y., Wen X., Lu Q. et al.: Heat stress induces an aggregation of the light-harvesting complex of photosystem II in spinach plants. - Plant Physiol. 143: 629-638, 2007.

van Peer R., Niemann G.J., Schippers B.: Induced resistance and phytoalexin accumulation in biological control of Fusarium wilt of carnation by Pseudomonas sp. strain WCS417r. Phytopathology 81: 728-34, 1991.

Vargas W.A., Mandawe J.C., Kenerley C.M.: Plant-derived sucrose is a key element in the symbiotic association between Trichoderma virens and maize plants. - Plant Physiol. 151: 792-80, 2009.

Vaz J., Sharma P.K.: Relationship between xanthophy cycle and non-photochemical quenching in rice (Oryza sativa L.) plants in response to light stress. - Indian J. Exp. Bot. 49: 60-67, 2011.

Wyse D.L.: Future of weed science research. - Weed Technol. 6: 162-165, 1992.

Yuan X.K.: Effect of day/night temperature difference on chlorophyll content, photosynthesis and fluorescence parameters of tomato at fruit stage. - Photosynthetica 54: 475477, 2016.

Zlatev Z.: Drought-induced changes in chlorophyll fluorescence of young wheat plant.- Biotechnology 23: 437-441, 2009. 